\title{
The Emerging Role of Non-Coding RNAs in the Regulation of Virus Replication and Resultant Cellular Pathologies
}

\author{
Soudeh Ghafouri-Fard ${ }^{1}\left(\mathbb{D}\right.$, Bashdar Mahmud Hussen ${ }^{2,3}\left(\mathbb{D}\right.$, , Hazha Hadayat Jamal ${ }^{4}$, Mohammad Taheri ${ }^{5, *}$ \\ and Guive Sharifi ${ }^{6, *}$
}

check for

updates

Citation: Ghafouri-Fard, S.

Hussen, B.M.; Jamal, H.H.; Taheri, M.; Sharifi, G. The Emerging Role of Non-Coding RNAs in the Regulation of Virus Replication and Resultant Cellular Pathologies. Int. J. Mol. Sci. 2022, 23, 815. https://doi.org/ $10.3390 /$ ijms 23020815

Academic Editor:

Constantinos Stathopoulos

Received: 1 December 2021

Accepted: 28 December 2021

Published: 13 January 2022

Publisher's Note: MDPI stays neutral with regard to jurisdictional claims in published maps and institutional affiliations.

Copyright: (C) 2022 by the authors. Licensee MDPI, Basel, Switzerland. This article is an open access article distributed under the terms and conditions of the Creative Commons Attribution (CC BY) license (https:// creativecommons.org/licenses/by/ $4.0 /)$.
1 Department of Medical Genetics, School of Medicine, Shahid Beheshti University of Medical Sciences Tehran P.O. Box 14155-6153, Iran; s.ghafourifard@sbmu.ac.ir

2 Department of Pharmacognosy, College of Pharmacy, Hawler Medical University, Erbil 44001, Iraq; Bashdar.Hussen@hmu.edu.krd

3 Center of Research and Strategic Studies, Lebanese French University, Erbil 44001, Iraq

4 Department of Biology, College of Education, Salahaddin University-Erbil, Erbil 44001, Iraq; hazha.hidayat@su.edu.krd

5 Institute of Human Genetics, Jena University Hospital, Am Klinikum 1, 07747 Jena, Germany

6 Skull Base Research Center, Loghman Hakim Hospital, Shahid Beheshti University of Medical Sciences, Tehran P.O. Box 14155-6153, Iran

* Correspondence: mohammad.taheri@uni-jena.de (M.T.); Guivesharifi@sbmu.ac.ir (G.S.)

\begin{abstract}
Non-coding RNAs, particularly lncRNAs and miRNAs, have recently been shown to regulate different steps in viral infections and induction of immune responses against viruses. Expressions of several host and viral lncRNAs have been found to be altered during viral infection. These lncRNAs can exert antiviral function via inhibition of viral infection or stimulation of antiviral immune response. Some other lncRNAs can promote viral replication or suppress antiviral responses. The current review summarizes the interaction between ncRNAs and herpes simplex virus, cytomegalovirus, and Epstein-Barr infections. The data presented in this review helps identify viral-related regulators and proposes novel strategies for the prevention and treatment of viral infection.
\end{abstract}

Keywords: long non-coding RNA; miRNA; HSV; EBV; CMV

\section{Introduction}

The human genome consists of a variety of non-protein-coding DNA. A proportion of these genomic regions are transcribed into RNA. These non-coding RNAs (ncRNAs) are believed to have diverse roles in cellular functions. In addition to those with characterized functions, further functional ncRNAs certainly need to be discovered and categorized [1]. Since the first evidence of biological functions of transfer and ribosomal RNAs in the 1950s, several other classes of ncRNAs have been identified. Two classes of these transcripts, namely, long ncRNAs (lncRNAs) and microRNAs (miRNAs), have gained special attention because of their regulatory roles on gene expression. While lncRNAs regulate gene expression at different levels, miRNAs mainly act at a post-transcriptional level. LncRNAs and miRNAs have another distinctive feature arising from their size. While the former group is longer than $200 \mathrm{nt}$, the latter are approximately $22 \mathrm{nt}$ in length. LncRNAs interplay with other RNA species, particularly miRNAs, in a way that they sequester them and decrease their bioavailability [2]. Besides this, IncRNAs have biological functions through serving as scaffolds and enhancer RNAs [3].

The regulatory role of miRNAs on gene expression is mediated through miRNAs pairing with the miRNA recognition elements in the mRNAs. These elements are found particularly in the 3' untranslated region (UTR) of transcripts; however, they are also present in $5^{\prime} \mathrm{UTR}$ and coding regions. When the RNA-induced silencing complex is recruited to miRNA recognition elements, the target mRNA is destabilized, or its expression 
is repressed [4]. Based on an individual miRNA's ability to target numerous miRNA recognition elements and suppression of hundreds of mRNAs, it is estimated that more than $60 \%$ of human protein-coding genes can be targeted by miRNAs [2].

NcRNAs, particularly lncRNAs, have recently been shown to regulate different steps in viral infections and induce immune responses against viruses [5]. Expressions of several host and viral lncRNAs have been found to be altered during viral infection [2,6]. These lncRNAs can exert antiviral function via inhibition of viral infection or stimulation of antiviral immune response. Some other lncRNAs can promote viral replication or suppress antiviral responses [2].

In the current review, we summarize the interaction between ncRNAs and herpes simplex virus (HSV), cytomegalovirus (CMV), and Epstein-Barr (EBV) infections.

\section{2. ncRNAs and HSV Infection}

Kaposi's sarcoma-associated HSV-encoded miRNAs have been shown to affect the expression of host lncRNAs such as Maternally Expressed 3 (MEG3), antisense non-coding RNA in the INK4 locus (ANRIL), and Urothelial Cancer Associated 1 (UCA1) in favor of cancer development. More than 120 host lncRNAs have been identified as putative targets for viral miRNAs. Notably, in addition to the miRNA-dependent route, this type of HSV can affect the expression of host lncRNAs through direct interactions between lncRNAs and latency-related proteins. The impact of HSV on UCA1 expression has pro-proliferative and pro-migratory effects on endothelial cells [7].

HSV-1 has also been shown to increase the expression of Nuclear Enriched Abundant Transcript 1 (NEAT1) and the establishment of paraspeckles through influencing Signal Transducer And Activator Of Transcription 3 (STAT3). NEAT1 and other paraspeckle constituents, namely, P54nrb and PSPC1, interact with HSV-1 genomic DNA. Paraspeckle Component 1 (PSPC1) binds with STAT3 to facilitate its recruitment to paraspeckles and increase its interplay with viral gene promoters. This interaction increases the expression of viral genes and the replication of viruses. Suppression of NEAT1 or STAT3 has improved the healing of HSV-1-related skin lesions in animal models [8]. Another study has shown that HSV infection can result in the construction of higher numbers of paraspeckles via increasing expression of NEAT1 [9]. NEAT1 has also been shown to cooperate with HEXIM1 to construct a multi-subunit complex that participates in the regulation of DNA-associated innate responses of the immune system. This complex encompasses DNA-PK subunits as well as paraspeckle proteins. In fact, binding of HEXIM1 to NEAT1 has an essential role in the assembly of this complex. This complex has a vital participation in induction of innate immune responses against foreign DNA via induction of cGAS-STING-IRF3 pathway [10].

A high throughput RNA sequencing experiment has shown over-expression of lncRNAs in murine $661 \mathrm{~W}$ cells following HSV-1 infection. U90926 RNA has been identified as the most over-expressed lncRNA after infection with this virus. Being located in the nucleus, U90926 enhanced replication of HSV-1 DNA and increased proliferation of this virus. U90926-silenced cells have exhibited higher survival rates [11].

During the latent phase of HSV infection, one region of its genome which encodes the latency-associated transcript (LAT) is not silenced. This lncRNA has been first identified as an enhancer of HSV-1 reactivation. Yet, subsequent studies have shown this lncRNA's role in the inhibition of cell apoptosis and enhancement of the formation of latency. Experiments in a rabbit model have revealed that reduction in LAT levels in neurons after the establishment of the latent phase decreases the capacity of HSV to reactivate. Thus, the HSV-1 LAT transcript is involved in the reactivation in an independent manner from its role in establishing latency [12].

Kaposi's sarcoma-associated HSV encodes a viral oncogene, namely, viral interferon regulatory factor 1 (vIRF1). This oncogene enhances migration potential and aggressiveness of endothelial cells through decreasing expression of miR-218-5p to release its targets HMGB2 and CMPK1 from its inhibitory effects. Functionally, vIRF1 suppresses the function of p53 to enhance the expression of DNA Methyltransferase 1 (DNMT1) and methylation of 
pre-miR-218-1 promoter (Figure 1). This process leads to the enhancement of the expression of OIP5 Antisense RNA 1 (OIP5-AS1), a lncRNA that sponges miR-218-5p. Cumulatively, the cellular lnc-OIP5-AS1/miR-218-5p axis is hijacked by vIRF1 to facilitate the invasiveness of HSV-associated tumors [13].

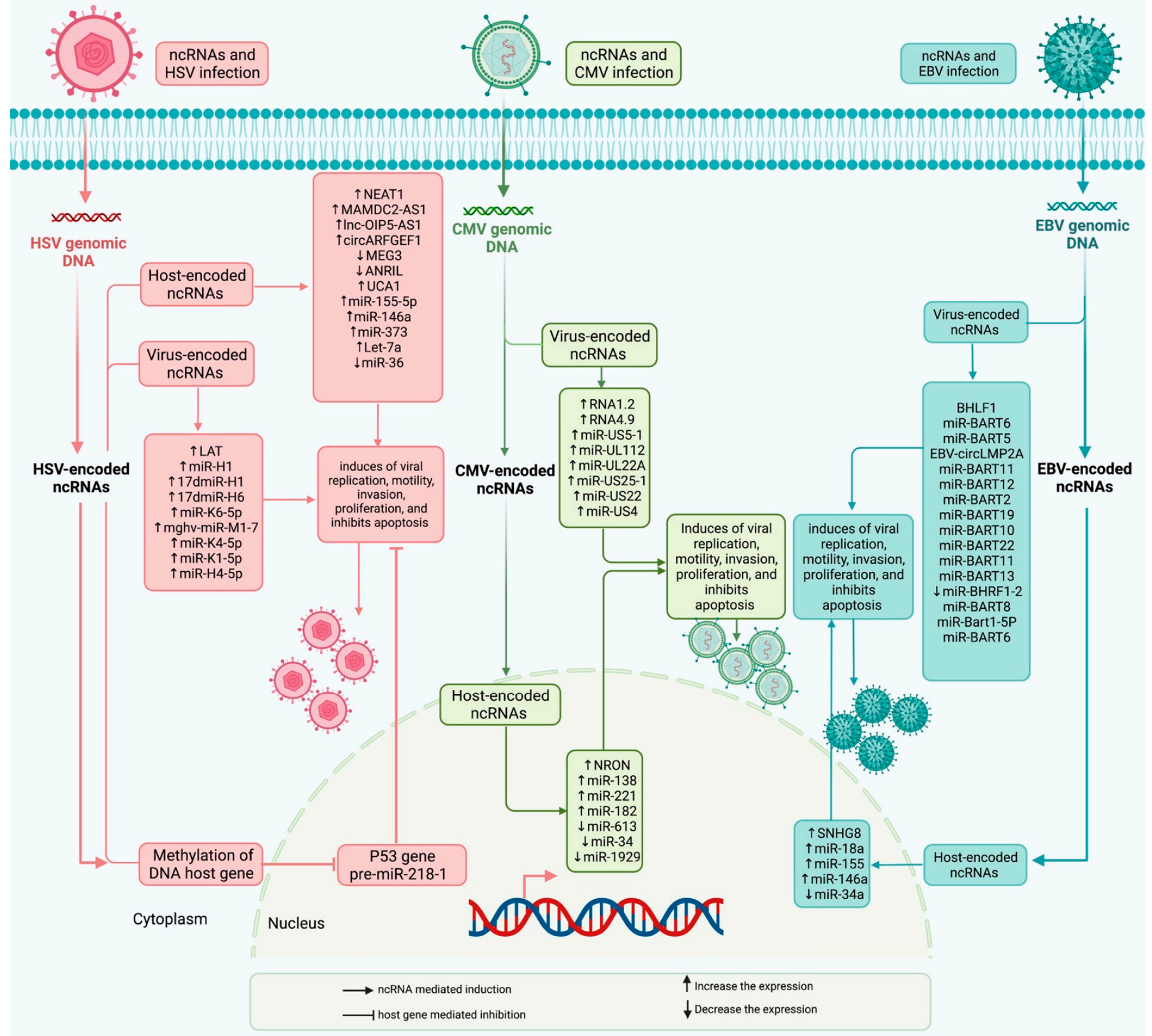

Figure 1. IncRNAs influence immune defense responses through directly interacting with host DNA genome, effecters, and transcriptional factors, and through releasing different types on non-coding RNAs, such as lncRNAs and miRNAs. Light pink represents HSV infection, light blue represents CMV infection, and pale turquoise represents EBV infection.

miR-H1 as an HSV-1-encoded miRNA has been shown to target Ubiquitin Protein Ligase E3 Component N-Recognin 1 (Ubr1) to increase amassing of neurodegenerationassociated protein [14]. Another study has demonstrated the role of miR-H1/H6 in the 
facilitation of effective reactivation from latency [15]. Moreover, HSV-1 has been shown to encode miR-H2-3p, a miRNA that interferes with cytosolic DNA-induced antiviral innate immune responses through decreasing expression of DEAD-Box Helicase 41 (DDX41) [16]. Tables 1 and 2 show the role of host and viral-encoded ncRNAs in HSV infection.

Table 1. Host-encoded ncRNAs and HSV infection (HEXIM1-DNA-PK-paraspeckle componentsribonucleoprotein complex (HDP-RNP), infected cell protein 0 (ICP0), thymidine kinase (TK), virion protein 16 (VP16), High-mobility-group protein 2 (HMGB2), SRSF2 (Serine and arginine Rich Splicing Factor 2), Interleukin-1 receptor-associated kinase (IRAK), RBPJ (Recombination Signal Binding Protein For Immunoglobulin Kappa J Region), interferon-induced transmembrane protein 1 (IFITM1)) ( $\uparrow$ upregulation; $\downarrow$ down regulation).

\begin{tabular}{|c|c|c|c|c|c|c|c|c|}
\hline ncRNA & $\begin{array}{c}\text { Expression } \\
\text { Pattern }\end{array}$ & $\begin{array}{l}\text { Clinical Sam- } \\
\text { ples/Animal } \\
\text { Model }\end{array}$ & $\begin{array}{l}\text { Cell } \\
\text { Culture }\end{array}$ & Targets & Regulators & $\begin{array}{l}\text { Signaling } \\
\text { Pathways }\end{array}$ & Description & Reference \\
\hline \multirow{2}{*}{ NEAT1 } & $\uparrow$ & - & HeLa, MEF & TK, ICP0 & - & - & $\begin{array}{l}\text { PSPC1 binds to STAT3 and } \\
\text { increases STAT3 binding to the } \\
\text { viral promoter, leading to } \\
\text { increased viral expression. } \\
\text { Knocking down STAT3 or NEAT1 } \\
\text { improves skin healing. }\end{array}$ & [8] \\
\hline & $\uparrow$ & - & $\begin{array}{l}\text { HeLa, } \\
\text { HeLa S3, } \\
\text { HEK293T, } \\
\text { HUVEC, }\end{array}$ & $\begin{array}{c}\text { HDP-RNP, } \\
\text { HEXIM1 }\end{array}$ & - & - & $\begin{array}{l}\text { NEAT1 assembles HDP-RNP, } \\
\text { which regulates innate immune } \\
\text { response against foreign DNA } \\
\text { through stabilizing the } \\
\text { host genome. }\end{array}$ & [10] \\
\hline U90926 & $\uparrow$ & - & $661 \mathrm{~W}$, Vero & ICP0, ICP4 & - & - & $\begin{array}{l}\text { After HSV-1 infection, } \\
\text { upregulation of U90926 results in } \\
\text { increased viral proliferation. }\end{array}$ & [11] \\
\hline $\begin{array}{c}\text { MAMDC2- } \\
\text { AS1 }\end{array}$ & $\uparrow$ & - & $\begin{array}{l}\text { 293T, A549, } \\
\text { HaCaT, } \\
\text { HepG2, } \\
\text { HFF, HeLa }\end{array}$ & $\begin{array}{l}\text { Hsp90 } \alpha, \\
\text { VP16 }\end{array}$ & YY1 & - & $\begin{array}{l}\text { This lncRNA increases HSV-1 } \\
\text { infection in human cells through } \\
\text { interacting with Hsp } 90 \alpha \text { and } \\
\text { importing HSV-1 into } \\
\text { the nucleus. }\end{array}$ & [17] \\
\hline MEG3 & $\downarrow$ & \multirow{3}{*}{-} & \multirow{3}{*}{$\begin{array}{l}\text { TIVE, } \\
\text { HUVEC, } \\
\text { HeLa, iSLK, } \\
\text { BCBL-1 }\end{array}$} & - & $\begin{array}{l}\text { miR-K12-3, } \\
\text { miR-K12-5, } \\
\text { miR-K12-6-5p, } \\
\text { miR-K12-8, } \\
\text { miR-K12-9 }\end{array}$ & \multirow{3}{*}{-} & \multirow{3}{*}{$\begin{array}{l}\text { During the active infection and } \\
\text { latency phase, HSV dysregulates } \\
\text { lncRNAs expression using its } \\
\text { miRNAs and proteins. Moreover, } \\
\text { UCA1 induction promotes cell } \\
\text { migration and proliferation. }\end{array}$} & \multirow{3}{*}{ [7] } \\
\hline ANRIL & $\downarrow$ & & & - & $\begin{array}{l}\text { miR-K12-1, } \\
\text { miR-K12-6-5p, } \\
\text { miR-K12-2, } \\
\text { miR-K12-11 }\end{array}$ & & & \\
\hline UCA1 & $\uparrow$ & & & - & $\begin{array}{l}\text { Kaposin and } \\
\text { vCyclin }\end{array}$ & & & \\
\hline $\begin{array}{l}\text { lnc-OIP5- } \\
\text { AS1 }\end{array}$ & $\uparrow$ & - & $\begin{array}{l}\text { iSLK, } \\
\text { HEK293T, } \\
\text { HUVECs }\end{array}$ & $\begin{array}{l}\text { miR-218-5p, } \\
\text { HMGB2, } \\
\text { CMPK1 }\end{array}$ & vIRF1 & - & $\begin{array}{l}\text { cIRF1 induces lnc-OIP5-AS1 } \\
\text { upregulation, which diminishes } \\
\text { miR-218-5p. As a result, in KSHV } \\
\text { cells, migration and proliferation } \\
\text { would be increased. }\end{array}$ & [13] \\
\hline circARFGEF1 & $\uparrow$ & - & $\begin{array}{l}\text { iSLK-RGB- } \\
\text { BAC16, } \\
\text { iSLK-RGB- } \\
\text { K9, } \\
\text { HUVECs, } \\
\text { HEK293T }\end{array}$ & $\begin{array}{l}\text { miR-125a- } \\
\text { 3p, } \\
\text { GLRX3 }\end{array}$ & vIRF1 & - & $\begin{array}{l}\text { As a circRNA, ARFGEF1is } \\
\text { induced by vIRF1. Moreover, } \\
\text { ARFGEF1 increases cell motility, } \\
\text { invasion, proliferation, and } \\
\text { angiogenesis in Kaposi's } \\
\text { sarcoma-associated herpesvirus } \\
\text { infected cells. }\end{array}$ & [18] \\
\hline miR-155-5p & $\uparrow$ & - & $\mathrm{HeLa}$ & SRSF2 & - & - & $\begin{array}{l}\text { This miRNA induces improved } \\
\text { levels of viral replication and } \\
\text { gene expression by regulating } \\
\text { SRSF2 promoter histones. }\end{array}$ & [19] \\
\hline miR-146a & $\uparrow$ & - & $\begin{array}{l}\text { THP-1, } \\
\text { HEp-2 }\end{array}$ & IRAK1 & - & $N F-k B$ & $\begin{array}{l}\text { miR-146a activates NF- } \mathrm{BB} \\
\text { signaling pathway in HSV-1 } \\
\text { infected cells. }\end{array}$ & [20] \\
\hline let-7a & $\uparrow$ & & $\begin{array}{c}\text { 293T, } \\
\text { iSLK.219 }\end{array}$ & RBPJ & LANA, LIN28B & $N F-\kappa B$ & $\begin{array}{l}\text { In Kaposi's sarcoma-associated } \\
\text { herpesvirus infected cells, let-7a } \\
\text { inhibits the lytic } \\
\text { reactivated phase. }\end{array}$ & [21] \\
\hline
\end{tabular}


Table 1. Cont.

\begin{tabular}{|c|c|c|c|c|c|c|c|c|}
\hline ncRNA & $\begin{array}{c}\text { Expression } \\
\text { Pattern }\end{array}$ & $\begin{array}{l}\text { Clinical Sam- } \\
\text { ples/Animal } \\
\text { Model }\end{array}$ & $\begin{array}{l}\text { Cell } \\
\text { Culture }\end{array}$ & Targets & Regulators & $\begin{array}{l}\text { Signaling } \\
\text { Pathways }\end{array}$ & Description & Reference \\
\hline miR-36 & $\downarrow$ & - & $\begin{array}{l}\text { BJAB, } \\
\text { HMVEC-d, } \\
\text { HFFs, } \\
\text { HEK293 }\end{array}$ & IFITM1 & - & - & $\begin{array}{l}\text { miR-36 overexpression lowers } \\
\text { IFITM1 levels, a protein induced } \\
\text { by Kaposi's sarcoma herpes } \\
\text { virus, leading to decreased } \\
\text { viral infection. }\end{array}$ & [22] \\
\hline $\operatorname{miR}-373$ & $\uparrow$ & $\begin{array}{l}\text { Serum } \\
\text { samples from } \\
10 \text { herpetic gin- } \\
\text { givostomatitis } \\
\text { and } 10 \\
\text { normal cases }\end{array}$ & $\mathrm{HeLa}$ & IRF1 & - & - & $\begin{array}{l}\text { miR-373 is overexpressed upon } \\
\text { HSV-1 infection, leading to } \\
\text { increased viral replication } \\
\text { and infection. }\end{array}$ & [23] \\
\hline
\end{tabular}

Table 2. Virus-encoded ncRNAs and HSV infection (DEAD-Box Helicase 41 (DDX41), EWSR1 (EWS RNA Binding Protein 1, Cytosolic arginine sensor for mTORC1 subunit 1 (CASTOR1), Suppressor Of Cytokine Signaling 2 (SOCS2)). ( $\uparrow$ upregulation; $\downarrow$ down regulation).

\begin{tabular}{|c|c|c|c|c|c|c|c|}
\hline ncRNA & $\begin{array}{l}\text { Expression } \\
\text { Pattern }\end{array}$ & $\begin{array}{l}\text { Clinical Sam- } \\
\text { ples/Animal } \\
\text { Model }\end{array}$ & Cell Culture & Targets & $\begin{array}{l}\text { Signaling } \\
\text { Pathways }\end{array}$ & Description & Reference \\
\hline \multirow[t]{2}{*}{ LAT } & $\uparrow$ & $\begin{array}{l}\text { Rabbit skin } \\
\text { cells }\end{array}$ & $\begin{array}{l}\text { primary rabbit } \\
\text { kidney cells }\end{array}$ & - & - & $\begin{array}{l}\text { LAT knockdown diminishes HSV-1 } \\
\text { reactivation in the latency phase. } \\
\text { Therefore, this lncRNA could be used as } \\
\text { a therapeutic target for herpes } \\
\text { stromal keratitis. }\end{array}$ & [12] \\
\hline & $\uparrow$ & $\begin{array}{l}\text { Human fetal } \\
\text { skin tissue, } \\
\text { SCID C.B-17 } \\
\text { male mice }\end{array}$ & - & - & - & $\begin{array}{l}\text { LAT is a remarkable factor in increasing } \\
\text { HSV-1 replication and lesion formation. }\end{array}$ & {$[24]$} \\
\hline miR-H1 & $\uparrow$ & - & $\begin{array}{l}\text { SH-SY5Y, } \\
\text { HEK293T }\end{array}$ & & - & $\begin{array}{l}\text { miR-H1, encoded by HSV-1, lowers } \\
\text { Ubr1, a ubiquitin-protein ligase, which } \\
\text { leads to } \beta \text {-amyloid accumulation. }\end{array}$ & [14] \\
\hline 17dmiR-H6 & $\uparrow$ & $\begin{array}{l}\text { female ND-40 } \\
\text { Swiss-Webster } \\
\text { mice, Male } \\
\text { and female } \\
\text { New Zealand } \\
\text { White rabbits }\end{array}$ & $\begin{array}{l}\text { CCL-13, } \\
\text { HEK293T }\end{array}$ & LAT & - & $\begin{array}{l}\text { Upon deleting these miRNAs, HSV-1 } \\
\text { loses the ability to reactivate. }\end{array}$ & [15] \\
\hline miR-K6-5p & $\uparrow$ & - & $\begin{array}{l}\text { HEK293T, } \\
\text { BC-3, BC-1, } \\
\text { JSC-1, BCBL-1 }\end{array}$ & $\begin{array}{l}\text { CCND3, } \\
\text { CDC25A }\end{array}$ & - & $\begin{array}{l}\text { In Kaposi's sarcoma-associated } \\
\text { herpesvirus, this miRNA is expressed } \\
\text { and as a tumor suppressor lowers cell } \\
\text { cycle progression. }\end{array}$ & [25] \\
\hline miR-H2-3p & $\uparrow$ & - & $\begin{array}{l}\text { HEK293T, } \\
\text { THP-1, HFF }\end{array}$ & $\begin{array}{l}\text { DDX41, } \\
\text { IFN- } \beta, \text { MxI }\end{array}$ & - & $\begin{array}{l}\text { miR-H2-3p lowers innate immune } \\
\text { response in infected cells and intensifies } \\
\text { viral DNA replication and proliferation. }\end{array}$ & [16] \\
\hline $\begin{array}{l}\text { mghv-miR- } \\
\text { M1-7-5p }\end{array}$ & $\uparrow$ & $\begin{array}{l}\text { C57BL/6J } \\
\text { mice }\end{array}$ & NIH3T12 & EWSR1 & - & $\begin{array}{l}\text { This miRNA is encoded by } \\
\text { gamma-herpesviruses and is a necessary } \\
\text { factor for its infection and } \\
\text { splenic latency. }\end{array}$ & {$[21]$} \\
\hline miR-K4-5p & $\uparrow$ & - & $\begin{array}{l}\text { TIVE, KTIVE, } \\
\text { MM, KMM }\end{array}$ & CASTOR1 & mTORC1 & $\begin{array}{l}\text { These two miRNAs are encoded by } \\
\text { Kaposi's sarcoma herpes virus and } \\
\text { could activate the mTORC1 signaling } \\
\text { pathway and improve cell proliferation }\end{array}$ & [26] \\
\hline miR-K1-5p & $\uparrow$ & & & & & and colony formation & \\
\hline miR-H4-5p & $\uparrow$ & - & $\mathrm{HeLa}$ & $\begin{array}{l}\text { CDKN2A, } \\
\text { CDKL2 }\end{array}$ & - & $\begin{array}{l}\text { miR-H4-5p is transcribed by HSV-2 and } \\
\text { induces cell cycle progression, } \\
\text { proliferation, and inhibits apoptosis. }\end{array}$ & {$[27]$} \\
\hline miR-H9-5p & $\uparrow$ & $\begin{array}{l}10 \text { cancerous } \\
\text { lung tissues } \\
\text { and } 10 \text { control } \\
\text { tissues }\end{array}$ & $\begin{array}{l}\text { LTEP- } \alpha-2, \\
\text { SPC- } \alpha-1\end{array}$ & SOCS2 & & $\begin{array}{c}\text { Transcribed by HSV-2 infection, } \\
\text { miR-H9-5p increases migration, } \\
\text { proliferation, and invasion of lung } \\
\text { cancer cells. }\end{array}$ & [28] \\
\hline
\end{tabular}

\section{3. ncRNAs and CMV Infection}

RNA1.2 has been recognized as one of four principal lncRNAs which are expressed by human CMV. This lncRNA has an essential function in manipulating the cellular NF-kB- 
dependent pathways of cytokine and chemokine production in the course of CMV infection. Thus, this IncRNA can affect host immune responses [29]. Another study has shown that human CMV encodes lncRNA4.9, which is localized to the viral replication compartment in the nucleus. Depletion of this lncRNA decreases CMVV DNA replication and its growth Notably, CRISPR-Cas9-mediated targeting the RNA4.9 promoter results in the reduction of viral ssDBP levels implying the relation between ssDBP levels and oriLyt activity [30].

An in vitro study has shown the ability of human CMV in infecting primary human mammary epithelial cells. This infection leads to inactivation of $\mathrm{Rb}$ and p53 proteins, enhancement of telomerase activity, and activation of c-Myc and Ras as well as Akt and STAT3 signaling pathways. CMV-transformed cells exhibited a CMV signature associated with the lncRNA4.9 gene. The sequence of this lncRNA has also been detected in xenograft tumors originated from CMV-transformed cells. Most notably, similar lncRNA4.9 genomic sequences have been found in tumor samples of breast cancer patients [31].

Persistent CMV infection in elderlies has been associated with down-regulation of Non-Coding Repressor Of NFAT (NRON) lncRNA, while up-regulation of its immunityassociated target gene NFAT, in both CD28nullCD8+ T cells and CMVpp65CD8+ T cells (Figure 1). Thus, NRON has been suggested to contribute to CMV-induced CD28nullCD8+ $\mathrm{T}$ cell aging through affecting IL-4-associated NFAT signals [32].

Experiments in animal models have shown that miR-1929-3p partakes in CMV-induced hypertensive vascular remodeling via inflammasome activation through Ednra/NOD-, LRR-, and pyrin domain-containing protein 3 (NLRP3) axis [33].

Another study has shown that human CMV encodes several ncRNAs such as miRUS5-1 and miR-UL112-3p that protect CD34+ hematopoietic progenitors from apoptosis through inactivation of Forkhead box class O 3a (FOXO3a) [34]. miR-UL112-3p has an established role in the enhancement of the progression of glioblastoma [35]. Tables 3 and 4 show the role of host and viral-encoded ncRNAs in CMV infection.

Table 3. Host-encoded ncRNAs and CMV infection (Endothelin-1 (ET-1), Sirtuin 1 (SIRT1), NLRP3 (NOD-, LRR-, and pyrin domain-containing protein 3), FOXO3a (Forkhead box class O 3a)). ( $\uparrow$ upregulation; $\downarrow$ down regulation).

\begin{tabular}{|c|c|c|c|c|c|c|c|}
\hline ncRNA & $\begin{array}{c}\text { Expression } \\
\text { Pattern }\end{array}$ & $\begin{array}{c}\text { Clinical } \\
\text { Samples/Animal } \\
\text { Model }\end{array}$ & $\begin{array}{l}\text { Cell } \\
\text { Culture }\end{array}$ & Targets & $\begin{array}{l}\text { Signaling } \\
\text { Pathways }\end{array}$ & Description & Reference \\
\hline NRON & $\uparrow$ & $\begin{array}{l}40 \text { elderly CMV } \\
\text { positive cases }\end{array}$ & - & NFAT & - & $\begin{array}{c}\text { Early CMV infection results in } \\
\text { increased NRON expression in all B } \\
\text { cell types. }\end{array}$ & [32] \\
\hline miR-1929-3p & $\downarrow$ & C57BL/6 J mice & - & $\begin{array}{l}\text { ET-1, Ednra, } \\
\text { NLRP3 }\end{array}$ & - & $\begin{array}{c}\text { CMV downregulates miR-1929-3p to } \\
\text { enhance blood pressure, endothelial } \\
\text { cell injury, and vascular remodeling in } \\
\text { mice. }\end{array}$ & [33] \\
\hline \multirow{2}{*}{ miR-138 } & $\uparrow$ & - & $\begin{array}{l}\text { HUVECs, } \\
\text { MRC-5 }\end{array}$ & $\begin{array}{c}\text { SIRT1, } \\
\text { p-STAT3 }\end{array}$ & - & $\begin{array}{c}\text { Endothelial cells infected by CMV } \\
\text { indicate a higher miR-138 expression, } \\
\text { which leads to tube formation and } \\
\text { migration. }\end{array}$ & [36] \\
\hline & $\uparrow$ & $\begin{array}{l}\text { Male BALB/c nude } \\
\text { mice }\end{array}$ & $\begin{array}{l}\text { MNK-45, } \\
\text { SGC-7901 }\end{array}$ & IL6R & - & $\begin{array}{l}\text { UL136 induces cell invasion and } \\
\text { proliferation by activating IL6/STAT3 } \\
\text { signaling, causing fluctuation in these } \\
\text { miRNAs' expression. }\end{array}$ & [37] \\
\hline $\operatorname{miR}-221$ & $\uparrow$ & C57BL/ 6 mice & $\begin{array}{l}\text { Neural } \\
\text { Precursor } \\
\text { Cells }\end{array}$ & SOCS1, IFN & $N F-\kappa B$ & $\begin{array}{l}\text { miR-221 hampers CMV replication in } \\
\text { cells through modulating the NF- } \mathrm{B} \text { B } \\
\text { signaling pathway. }\end{array}$ & [38] \\
\hline miR-182 & $\uparrow$ & $\begin{array}{l}\text { Female Balb/c } \\
\text { mice }\end{array}$ & $\begin{array}{l}\text { U-251MG, } \\
\text { HFFs, NPCs }\end{array}$ & $\begin{array}{l}\text { IRF7, } \\
\text { FOXO3, } \\
\text { IFN-I }\end{array}$ & - & $\begin{array}{l}\text { CMV infection increases miR-182 } \\
\text { expression, which itself produces } \\
\text { IFN-I to restrict CMV replication. }\end{array}$ & [39] \\
\hline miR-613 & $\downarrow$ & $\begin{array}{l}\text { 10 CMV-positive } \\
\text { and } 10 \\
\text { CMV-negative } \\
\text { glioblastoma } \\
\text { tissues and their } \\
\text { adjacent normal } \\
\text { tissues }\end{array}$ & U87, U251 & Arginase-2 & - & $\begin{array}{l}\text { In glioblastoma infected cells and } \\
\text { tissues, miR-613 is negatively } \\
\text { correlated with tumor size, stage, and } \\
\text { patients' survival rates. Moreover, it } \\
\text { could diminish colony formation, } \\
\text { migration, and invasion. }\end{array}$ & [40] \\
\hline
\end{tabular}


Table 4. Virus-encoded ncRNAs and CMV infection (Tumor protein p63-regulated gene 1-like protein (TPRG1L), Monocyte Chemoattractant Protein-1 (MCP-1), CXCL1 (C-X-C Motif Chemokine Ligand 1, BCL2L11 (BCL2 Like 11), TUSC3 (Tumor Suppressor Candidate 3), GAB1 (GRB2 Associated Binding Protein 1)). ( $\uparrow$ upregulation; $\downarrow$ down regulation).

\begin{tabular}{|c|c|c|c|c|c|c|c|}
\hline ncRNA & $\begin{array}{c}\text { Expression } \\
\text { Pattern }\end{array}$ & $\begin{array}{l}\text { Clinical Sam- } \\
\text { ples/Animal } \\
\text { Model }\end{array}$ & Cell Culture & Targets & $\begin{array}{l}\text { Signaling } \\
\text { Pathways }\end{array}$ & Description & Reference \\
\hline RNA1.2 & $\uparrow$ & - & $\begin{array}{l}\text { HFFF2, } \\
\text { HEK293T, } \\
\text { HFT }\end{array}$ & $\begin{array}{l}\text { TPRG1L, } \\
\text { IL-6, } \\
\text { MCP-1, } \\
\text { CXCL1 }\end{array}$ & NF- $k B$ & $\begin{array}{l}\text { RNA1.2, encoded by CMV, } \\
\text { modifies the expression of } \\
\text { many genes, which is a } \\
\text { conspicuous indication of } \\
\text { modulating the NF- } \mathrm{kB} \\
\text { signaling pathway. }\end{array}$ & [29] \\
\hline \multirow{2}{*}{ RNA4.9 } & $\uparrow$ & - & MEF & ssDBP & - & $\begin{array}{l}\text { Located in the nucleus, RNA4.9 } \\
\text { improves viral growth and } \\
\text { DNA replication. }\end{array}$ & [30] \\
\hline & $\uparrow$ & $\begin{array}{c}\text { female } \\
\text { NOD/SCID } \\
\text { Gamma mice }\end{array}$ & $\begin{array}{l}\text { MDA-MB- } \\
\text { 231, MCF-7, } \\
\text { HMECs }\end{array}$ & - & - & $\begin{array}{l}\text { CMV infection induces RNA4.9 } \\
\text { expression, which leads to } \\
\text { tumor formation. }\end{array}$ & [31] \\
\hline miR-US5-1 & $\uparrow$ & - & $\begin{array}{c}\text { CD34+ HPCs } \\
\text { of fetal liver } \\
\text { tissues, THF, } \\
\text { NHDF, } \\
\text { HEK293 }\end{array}$ & $\begin{array}{l}\text { FOXO3a, } \\
\text { BCL2L11 }\end{array}$ & MAPK & $\begin{array}{l}\text { CMV downregulates } \\
\text { pro-apoptotic proteins and } \\
\text { increases CD } 34^{+} \\
\text {progenitor cells. }\end{array}$ & [34] \\
\hline miR-UL112-3p & $\uparrow$ & $\begin{array}{l}40 \text { CMV-positive } \\
\text { glioblastoma and } \\
\text { adjacent normal } \\
\text { tissues }\end{array}$ & $\begin{array}{l}\text { Glioblastoma } \\
\text { primary } \\
\text { culture, } \\
\text { HEK293 }\end{array}$ & TUSC3 & Akt & $\begin{array}{l}\text { miR-UL112-3p improves } \\
\text { glioblastoma cells proliferation, } \\
\text { migration, invasion, and } \\
\text { colony formation. }\end{array}$ & [35] \\
\hline \multirow[b]{2}{*}{ miR-US5-2 } & $\downarrow$ & - & $\begin{array}{c}\text { NHDF, } \\
\text { hAECs, 293T }\end{array}$ & $\begin{array}{l}\text { GAB1, } \\
\text { UL138, } \\
\text { EGR1 }\end{array}$ & PI3k/ERK & $\begin{array}{l}\text { This miRNA can thwart the } \\
\text { normal EGF signaling pathway } \\
\text { that boosts cell proliferation. }\end{array}$ & [41] \\
\hline & $\uparrow$ & \multirow[t]{2}{*}{-} & \multirow{2}{*}{$\begin{array}{l}\text { NHDF, } \\
\text { HEK293T, } \\
\text { CC-2535 }\end{array}$} & $\begin{array}{l}\text { TGF- } \beta \text {, } \\
\text { NAB1 }\end{array}$ & \multirow[t]{2}{*}{-} & $\begin{array}{l}\text { HCMV miR-US5-2 is a latent } \\
\text { miRNA that suppresses } \\
\text { uninfected CD34 } \\
\text { hematopoietic progenitor cells. }\end{array}$ & \multirow{2}{*}{ [42] } \\
\hline miR-UL22A & $\uparrow$ & & & SMAD3 & & $\begin{array}{l}\text { By diminishing SMAD3, this } \\
\text { miRNA reactivates CMV in } \\
\text { CD } 34^{+} \text {cells. }\end{array}$ & \\
\hline miR-US22 & $\uparrow$ & - & $\begin{array}{l}\text { HEK293T, } \\
\text { NHDF, AEC }\end{array}$ & EGR1 & - & $\begin{array}{c}\text { miR-US22 lowers } \\
\text { hematopoietic stem cells } \\
\text { proliferation, self-renewal, and } \\
\text { colony formation. }\end{array}$ & [43] \\
\hline miR-US25-1-5p & $\uparrow$ & - & $\begin{array}{l}\text { HFF, U251, } \\
\text { HEK293 }\end{array}$ & $\begin{array}{l}\text { CD147, } \\
\text { IFN- } \beta\end{array}$ & NF-kB & $\begin{array}{l}\text { miR-US25-1-5p diminishes } \\
\text { antiviral immune response and } \\
\text { CD147 but induces the lytic } \\
\text { phase of CMV virus. }\end{array}$ & [44] \\
\hline miR-US4-5p & $\uparrow$ & - & $\begin{array}{l}\text { HELF, } \\
\text { HEK293, } \\
\text { THP-1 }\end{array}$ & PAK2 & - & $\begin{array}{l}\text { miR-US4-5p, encoded by CMV, } \\
\text { inhibits apoptosis by } \\
\text { downregulating PAK } 2 .\end{array}$ & [45] \\
\hline
\end{tabular}

\section{4. ncRNAs and EBV Infection}

Nasopharyngeal carcinoma is one of the EBV-associated cancers. EBV has been shown to express very few viral proteins in nasopharyngeal carcinoma cells, probably in order to evade induction of immune responses. Yet, it expresses high amounts of EBV BamHI-A region rightward transcript (BART) miRNAs and lncRNAs (Figure 1). These ncRNAs are implicated in the pathogenesis of EBV-related disorders. The expression of BARTs has been shown to be regulated by the NF- $\mathrm{KB}$ pathway. In fact, EBV LMP1 as an effective activator of the NF-KB pathway can increase the expression of BARTs via this pathway. Meanwhile, BART miRNAs can decrease the expression of LMP1. NF- $\mathrm{kB}$ pathway and expression 
of BARTs construct an autoregulatory circuit to preserve EBV latency in nasopharyngeal carcinoma cells [46].

BHLF1 gene of EBV has been shown to encode several lncRNAs in linear and circular forms that participate in viral replication. However, an open reading frame has been detected in this gene in a proportion of EBV isolates. BHLF1 transcripts have also been detected during the latent phase. In fact, this lncRNA participates in important features of EBV latency, such as its capacity to induce the constant proliferation of B lymphocytes and their malignant transformation [47]. On the other hand, the EBV-encoded miRNA miR-BART6-3p has been shown to act as a tumor suppressor. This miRNA could inhibit metastasis and invasion processes and suppress the proliferation of EBV-related neoplasms via decreasing the expression of LOC553103. LOC553103 has been found to directly bind with the 3'UTR of STMN1 and increase its stability. Cumulatively, miR-BART63p/LOC553103/STMN1 molecular route can modulate levels of cell cycle-related proteins, which subsequently suppress the EBV-related proliferation of tumor cells [48].

Over-expression of EBV-miR-BART5-3p has been shown to promote the growth of nasopharyngeal and gastric cancer cells. This miRNA can directly target 3'UTR of TP53 and subsequently decrease Cyclin Dependent Kinase Inhibitor 1A (CDKN1A), BCL2 Associated X, Apoptosis Regulator (BAX), and Fas Cell Surface Death Receptor expression levels. Thus, this miRNA accelerates cell cycle progression and inhibits cell apoptosis. Most notably, BART5-3p participates in chemo/radioresistance. Furthermore, it increases p53 protein degradation [49].

Huang et al. have sequenced more than 11,000 lncRNAs and 144,000 protein-coding transcripts from four EBV-associated and EBV-negative gastric cancer samples in addition to their adjacent unaffected tissues. They have shown specific expression of SNHG8 in EBVassociated gastric cancer. This lncRNA has been demonstrated to influence the activity of numerous gastric cancer-specific signaling pathways and genes being affected by EBV [50]. Tables 5 and 6 show the role of host and viral-encoded ncRNAs in EBV infection.

Table 5. Host-encoded ncRNAs and EBV infection (TRIM28 (Tripartite Motif Containing 28), EIF4A2 (Eukaryotic Translation Initiation Factor 4A2), NAP1L1 (Nucleosome Assembly Protein 1 Like 1), PLD3 (Phospholipase D Family Member 3), RPL18A (Ribosomal Protein L18a), SMAD2 (SMAD Family Member 2), CXCR4 (C-X-C Motif Chemokine Receptor 4), Programmed death-ligand 1 (PD-L1)). ( $\uparrow$ upregulation; $\downarrow$ down regulation).

\begin{tabular}{|c|c|c|c|c|c|c|c|c|}
\hline ncRNA & $\begin{array}{c}\text { Expression } \\
\text { Pattern }\end{array}$ & $\begin{array}{l}\text { Clinical Sam- } \\
\text { ples/Animal } \\
\text { Model }\end{array}$ & Cell Culture & Targets & Regulators & $\begin{array}{l}\text { Signaling } \\
\text { Pathways }\end{array}$ & Description & Reference \\
\hline SNHG8 & $\uparrow$ & $\begin{array}{l}88 \text { gastric } \\
\text { cancer and } \\
\text { adjacent } \\
\text { normal tissues }\end{array}$ & - & $\begin{array}{l}\text { TRIM28, } \\
\text { EIF4A2, } \\
\text { NAP1L1, } \\
\text { PLD3, } \\
\text { RPL18A, } \\
\text { TRPM7 }\end{array}$ & & - & $\begin{array}{l}\text { SNHG8 is up-regulated in } \\
\text { gastric cancer tissues afflicted } \\
\text { with the EBV virus and may } \\
\text { trigger cancer initiation by } \\
\text { altering various proteins. }\end{array}$ & [50] \\
\hline miR-18a & $\uparrow$ & $\begin{array}{l}21 \text { cancerous } \\
\text { and } 14 \\
\text { non-cancerous } \\
\text { tissues, male } \\
\text { BALB } / \text { c nude } \\
\text { mice }\end{array}$ & $\begin{array}{l}\text { CNE1, CNE2, } \\
\text { S-18, S-26, 5-8F, } \\
\text { 6-10B, SUNE2, } \\
\text { C666-1 }\end{array}$ & SMG1 & LAT & $N F-\kappa B$ & $\begin{array}{l}\text { In EBV-positive cases, miR-182 } \\
\text { positively correlates with } \\
\text { nasopharyngeal tumor size } \\
\text { and tumor stage. Moreover, it } \\
\text { enhances cell migration, } \\
\text { invasion, and proliferation. }\end{array}$ & [51] \\
\hline miR-155-5p & $\uparrow$ & - & $\begin{array}{l}\text { GT38, GT39, } \\
\text { SNU719, } \\
\text { HGC27, } \\
\text { SGC7901, } \\
\text { BGC823 }\end{array}$ & Smad2 & LMP2A & $\begin{array}{l}\text { NF- } \kappa B \text {, } \\
\text { TGF- } \beta\end{array}$ & $\begin{array}{l}\text { In EBV-infected gastric cancer } \\
\text { cells, miR-155-5p reduces cell } \\
\text { proliferation and boosts cell } \\
\text { cycle arrest and apoptosis. }\end{array}$ & [52] \\
\hline miR-146a & $\uparrow$ & - & $\begin{array}{l}\text { GT38, GT39, } \\
\text { AGS, BGC823, } \\
\text { SGC7901 }\end{array}$ & CXCR4 & LMP1 & - & $\begin{array}{l}\text { EBV induces miR-146a } \\
\text { expression, which leads to } \\
\text { lower cell proliferation, } \\
\text { migration, and cell } \\
\text { cycle progression. }\end{array}$ & [53] \\
\hline
\end{tabular}


Table 5. Cont.

\begin{tabular}{|c|c|c|c|c|c|c|c|c|}
\hline ncRNA & $\begin{array}{c}\text { Expression } \\
\text { Pattern }\end{array}$ & $\begin{array}{l}\text { Clinical Sam- } \\
\text { ples/Animal } \\
\text { Model }\end{array}$ & Cell Culture & Targets & Regulators & $\begin{array}{l}\text { Signaling } \\
\text { Pathways }\end{array}$ & Description & Reference \\
\hline \multirow[t]{2}{*}{ miR-34a } & $\downarrow$ & $\begin{array}{l}27 \text { diffuse } \\
\text { large B-cell } \\
\text { lymphoma } \\
\text { cases }\end{array}$ & $\begin{array}{c}\text { LCL, OMA4, } \\
\text { DG75, BL41, } \\
\text { U2932, } \\
\text { SUDHL5, } \\
\text { ER/EB 2.5, } \\
\text { Mutu I, Mutu } \\
\text { III, Daudi, } \\
\text { Jijoye }\end{array}$ & PD-L1 & EBF1 & - & $\begin{array}{l}\text { In Burkitt lymphoma and } \\
\text { diffuse large B-cell lymphomas, } \\
\text { miR-34a acts as a tumor } \\
\text { suppressor due to } \\
\text { downregulating PD-L1 and } \\
\text { activating T cells. }\end{array}$ & [54] \\
\hline & $\downarrow$ & - & $\begin{array}{l}\text { SNU719, } \\
\text { SNU638 }\end{array}$ & NOX2 & EBNA1 & - & $\begin{array}{l}\text { In gastric cancer cell lines, } \\
\text { miR-34a downregulation leads } \\
\text { to increased cell viability and } \\
\text { reduced apoptosis rate. }\end{array}$ & [55] \\
\hline
\end{tabular}

Table 6. Virus-encoded ncRNAs and EBV infection (AT-rich interactive domain-containing protein 1A (ARID1A), latent membrane protein 1 (LMP1), Tubulin polymerization promoting protein 1 (Tppp1), DKK1 (Dickkopf WNT Signaling Pathway Inhibitor 1), NKIRAS2 (NFKB Inhibitor Interacting Ras Like 2)). ( $\uparrow$ upregulation; $\downarrow$ down regulation).

\begin{tabular}{|c|c|c|c|c|c|c|c|}
\hline ncRNA & $\begin{array}{c}\text { Expression } \\
\text { Pattern }\end{array}$ & $\begin{array}{c}\text { Clinical } \\
\text { Samples/Animal } \\
\text { Model }\end{array}$ & Cell Culture & Targets & $\begin{array}{l}\text { Signaling } \\
\text { Pathways }\end{array}$ & Description & Reference \\
\hline BHLF1 & $\uparrow$ & - & $\begin{array}{l}\text { A.21, Kem I, } \\
\text { Mutu I, BX1, } \\
\text { HEK } 293\end{array}$ & - & - & $\begin{array}{l}\text { After being up-regulated by SM } \\
\text { protein, BHLF1 encodes ncRNAs } \\
\text { that induce a latency phase, } \\
\text { immortalize EBV, and generate B } \\
\text { cells growth. }\end{array}$ & [47] \\
\hline miR-BART6-3p & $\uparrow$ & $\begin{array}{l}\text { female BALB } / \mathrm{c} \\
\text { nude mice }\end{array}$ & $\begin{array}{l}\text { 5-8 F, HNE2, } \\
\text { C666-1, } \\
\text { HEK293T }\end{array}$ & $\begin{array}{l}\text { LOC553103, } \\
\text { STMN1 }\end{array}$ & - & $\begin{array}{l}\text { Invasion, cell cycle progression, } \\
\text { and metastasis of tumors are all } \\
\text { diminished by this miRNA. }\end{array}$ & [48] \\
\hline \multirow[t]{2}{*}{ miR-BART5-5p } & $\uparrow$ & - & $\begin{array}{l}\text { CNE2, HeLa-Bx1, } \\
\text { HEK293T, } \\
\text { C666-1 }\end{array}$ & LMP1 & $N F-\kappa B$ & $\begin{array}{l}\text { Through the NF- } \mathrm{kB} \text { pathway, } \\
\text { LMP1 activates the BART } \\
\text { promoters in nasopharyngeal } \\
\text { carcinoma. BART itself could } \\
\text { downregulate LMP1 expression } \\
\text { as well. }\end{array}$ & [46] \\
\hline & $\uparrow$ & $\begin{array}{l}24 \text { gastric cancer } \\
\text { patients, nude } \\
\text { mice }\end{array}$ & $\begin{array}{l}\text { SGC7901, GES1, } \\
\text { HNE1, 6-10B, } \\
\text { AGS }\end{array}$ & $\begin{array}{l}\text { TP53, } \\
\text { CDKN1A, } \\
\text { BAX, FAS }\end{array}$ & - & $\begin{array}{l}\text { Aside from increasing the } \\
\text { resistance to chemotherapeutic } \\
\text { agents, miR-BART5- } 5 \text { p improves } \\
\text { cell cycle progression and growth } \\
\text { in cancerous tissues. }\end{array}$ & [49] \\
\hline EBV-circLMP2A & $\uparrow$ & $\begin{array}{l}78 \text { gastric cancer } \\
\text { patients, female } \\
\text { NOD/SCID } \\
\text { mice }\end{array}$ & $\begin{array}{l}\text { SNU719, } \\
\text { YCCEL1, } \\
\text { HEK293T }\end{array}$ & $\begin{array}{l}\text { miR-3908, } \\
\text { TRIM59, p53 }\end{array}$ & - & $\begin{array}{c}\text { This circRNA is encoded by EBV } \\
\text { and has a remarkable association } \\
\text { with poor prognosis and } \\
\text { metastasis in EBV-associated } \\
\text { gastric cancer cases. Furthermore, } \\
\text { it induces stemness in cancerous } \\
\text { cells. }\end{array}$ & [56] \\
\hline
\end{tabular}


Table 6. Cont.

\begin{tabular}{|c|c|c|c|c|c|c|c|}
\hline ncRNA & $\begin{array}{c}\text { Expression } \\
\text { Pattern }\end{array}$ & $\begin{array}{l}\text { Clinical } \\
\text { Samples/Animal } \\
\text { Model }\end{array}$ & Cell Culture & Targets & $\begin{array}{l}\text { Signaling } \\
\text { Pathways }\end{array}$ & Description & Reference \\
\hline miR-BART11-3p & $\uparrow$ & $\begin{array}{l}20 \text { EBV positive } \\
\text { and } 2 \text { EBV }\end{array}$ & MKN7, NCI-N87 & ARID1A & - & $\begin{array}{l}\text { These two miRNAs bind } \\
\text { ARID1A, a tumor suppressor, } \\
\text { and decrease its level in gastric }\end{array}$ & [57] \\
\hline \multirow{3}{*}{ miR-BART12 } & $\uparrow$ & & & & & cancer tumors. & \\
\hline & $\uparrow$ & $\begin{array}{c}27 \text { cancerous and } \\
13 \\
\text { nasopharyngeal } \\
\text { epithelial tissues, } \\
\text { male BALB/c } \\
\text { nude mice }\end{array}$ & $\begin{array}{l}\text { C666-1, 5-8F, } \\
\text { AGS }\end{array}$ & ТРPР1 & - & $\begin{array}{l}\text { This miRNA increases the } \\
\text { invasion, EMT, and migration } \\
\text { rate in EBV-related tumors by } \\
\text { hampering } \alpha \text {-tubulin acetylation } \\
\text { and remodeling the cytoskeleton. } \\
\text { It is also correlated with a poor } \\
\text { prognosis rate. }\end{array}$ & [58] \\
\hline & $\uparrow$ & \multirow{4}{*}{$\begin{array}{l}55 \\
\text { nasopharyngeal } \\
\text { tumors and } 21 \\
\text { normal tissues }\end{array}$} & \multirow{4}{*}{$\begin{array}{c}\text { C666-1, NPC43, } \\
\text { C17, HK1, NP69, } \\
\text { C15, HeLa, } \\
\text { 293FT }\end{array}$} & \multirow{4}{*}{ BRCA1 } & \multirow{4}{*}{-} & \multirow{4}{*}{$\begin{array}{l}\text { These miRNAs downregulate } \\
\text { BRCA1 and potentiate cancerous } \\
\text { cells to chemotherapy. }\end{array}$} & \multirow{4}{*}{ [59] } \\
\hline miR-BART2-3p & $\uparrow$ & & & & & & \\
\hline miR-BART17-5p & $\uparrow$ & & & & & & \\
\hline \multirow[b]{2}{*}{ miR-BART19-3p } & $\uparrow$ & & & & & & \\
\hline & $\uparrow$ & $\begin{array}{l}20 \text { chronic active } \\
\text { EBV infection, } 20 \\
\text { EBV-associated } \\
\text { hemophagocytic } \\
\text { lymphohistiocy- } \\
\text { tosis, } 10 \text { healthy } \\
\text { cases }\end{array}$ & $\begin{array}{c}\text { AGS, C666-1, } \\
\text { B95-8, Akata-Bx1 }\end{array}$ & $\mathrm{APC}$ & - & $\begin{array}{l}\text { miR-BART19-3p is increased in } \\
\text { these diseases and induces cell } \\
\text { proliferation, and inhibits cell } \\
\text { apoptosis. }\end{array}$ & {$[60]$} \\
\hline \multirow[t]{2}{*}{ miR-BART10-3p } & $\uparrow$ & - & $\begin{array}{l}\text { AGS, SNU-719, } \\
\text { HEK293T }\end{array}$ & DKK1 & - & $\begin{array}{l}\text { In gastric cancer cells infected by } \\
\text { EBV, this miRNA increases cell } \\
\text { proliferation and migration. }\end{array}$ & [61] \\
\hline & $\uparrow$ & \multirow{2}{*}{$\begin{array}{l}874 \text { gastric } \\
\text { cancerous tissues }\end{array}$} & \multirow{2}{*}{$\begin{array}{l}\text { SNU719, } \\
\text { YCCEL1, } \\
\text { BGC823, AGS }\end{array}$} & \multirow{2}{*}{$\begin{array}{l}\text { APC, DKK1, } \\
\text { Twist }\end{array}$} & \multirow{2}{*}{ Wnt } & \multirow{2}{*}{$\begin{array}{l}\text { These miRNAs induce invasion } \\
\text { and migration and are indicators } \\
\text { of a lower survival rate. }\end{array}$} & \multirow[t]{2}{*}[62]{} \\
\hline miR-BART22 & $\uparrow$ & & & & & & \\
\hline miR-BART11 & $\uparrow$ & $\begin{array}{l}36 \text { gastric cancer } \\
\text { tissues, blood } \\
\text { samples from } \\
102 \text { gastric } \\
\text { patients, and } 112 \\
\text { healthy controls }\end{array}$ & $\begin{array}{c}\text { AGS, THP-1, } \\
\text { MKN-45, } \\
\text { SGC-7901, 293T }\end{array}$ & FOXP1 & - & $\begin{array}{c}\text { EMT is significantly increased by } \\
\text { this miRNA. Moreover, it } \\
\text { negatively correlates with a } \\
\text { lower survival rate. }\end{array}$ & [63] \\
\hline miR-BART1-5p & $\uparrow$ & $\begin{array}{l}28 \text { EBV-positive } \\
\text { and } 31 \\
\text { EBV-negative } \\
\text { gastric cancer } \\
\text { patients. }\end{array}$ & $\begin{array}{l}\text { GT38, GT39, } \\
\text { SNU719, AGS, } \\
\text { HGC27, BGC823, } \\
\text { SGC7901, } \\
\text { HEK293T }\end{array}$ & GCNT3 & NF-kB & $\begin{array}{l}\text { miR-BART1-5p inhibits cell } \\
\text { migration and invasion in } \\
\text { EBV-infected gastric cancer cells. }\end{array}$ & [64] \\
\hline miR-BART13-3p & $\uparrow$ & $\begin{array}{l}24 \text { cancerous } \\
\text { tissues, BALB/c } \\
\text { nude mice }\end{array}$ & $\begin{array}{l}\text { CNE1, S26, } \\
\text { CNE2, 5-8F, } \\
\text { HEK293T }\end{array}$ & $\mathrm{ABI} 2$ & $\begin{array}{c}\mathrm{c}- \\
\mathrm{JUN} / \mathrm{SLUG}\end{array}$ & $\begin{array}{c}\text { This miRNA could induce EMT, } \\
\text { migration, and invasion in } \\
\text { nasopharyngeal carcinoma } \\
\text { through the c-JUN/SLUG } \\
\text { pathway. }\end{array}$ & [65] \\
\hline \multirow[t]{2}{*}{ miR-BHRF1-2-5p } & $\downarrow$ & - & $\begin{array}{l}\text { PBMCs from } \\
\text { healthy cases }\end{array}$ & $\begin{array}{l}\text { PD-L1, PD-L2, } \\
\text { LMP1 }\end{array}$ & - & $\begin{array}{c}\text { In progenitor B cells, } \\
\text { miR-BHRF1-2-5p manipulates } \\
\text { apoptosis-related molecules, } \\
\text { insinuating its significant role in } \\
\text { B cell lymphomas. }\end{array}$ & {$[66]$} \\
\hline & $\downarrow$ & - & $\begin{array}{l}\text { BJAB, HEK293T, } \\
\text { isolated primary } \\
\text { B lymphocytes }\end{array}$ & IL1R1, TYW3 & $\mathrm{NF}-\kappa \mathrm{B}$ & $\begin{array}{l}\text { miR-BHRF1-2-5p blocks NF- } \mathrm{B} \\
\text { activation and IL-1 signaling. }\end{array}$ & {$[44]$} \\
\hline \multirow[b]{2}{*}{ miR-BART8-3p } & $\uparrow$ & male nude mice & HONE1, 5-8F & $\begin{array}{l}\gamma-\mathrm{H} 2 \mathrm{AX} \\
\text { CCNB1, } \\
\text { CDK1, CHK1, } \\
\text { CHK2 }\end{array}$ & ATM/ATR & $\begin{array}{c}\text { miR-BART8-3p, encoded by EBV, } \\
\text { enhances tumor size, cell } \\
\text { proliferation, and resistance to } \\
\text { radiation therapy by activating } \\
\text { the ATM/ATR pathway. }\end{array}$ & [53] \\
\hline & $\uparrow$ & $\begin{array}{l}19 \text { cancerous and } \\
10 \text { normal } \\
\text { nasopharyngeal } \\
\text { tissues, female } \\
\text { BALB/c } \\
\text { nude mice }\end{array}$ & $\begin{array}{l}\text { CNE-1, SUNE-1, } \\
\text { HEK293T, } \\
\text { C666-1 }\end{array}$ & RNF38 & $\begin{array}{l}\text { NF-kB, } \\
\text { Erk1/2 }\end{array}$ & $\begin{array}{l}\text { miR-BART8-3p escalates } \\
\text { migration, EMT, invasion, and } \\
\text { metastasis in nasopharyngeal } \\
\text { cancerous cells. }\end{array}$ & [67] \\
\hline
\end{tabular}


Table 6. Cont.

\begin{tabular}{|c|c|c|c|c|c|c|c|}
\hline ncRNA & $\begin{array}{c}\text { Expression } \\
\text { Pattern }\end{array}$ & $\begin{array}{c}\text { Clinical } \\
\text { Samples/Animal } \\
\text { Model }\end{array}$ & Cell Culture & Targets & $\begin{array}{l}\text { Signaling } \\
\text { Pathways }\end{array}$ & Description & Reference \\
\hline miR-BART13 & $\uparrow$ & $\begin{array}{c}36 \\
\text { nasopharyngeal } \\
\text { cancerous and } 25 \\
\text { normal tissues, } \\
\text { female BALB/c } \\
\text { nude mice }\end{array}$ & $\begin{array}{c}\text { CNE-1, 293T, } \\
\text { C666-1, SUNE-1 }\end{array}$ & NKIRAS2 & $N F-\kappa B$ & $\begin{array}{l}\text { miR-BART13 improves EMT, } \\
\text { metastasis, tumor growth, and } \\
\text { cell proliferation in cancerous } \\
\text { cells by activating the NF- } \mathrm{KB} \\
\text { signaling pathway. }\end{array}$ & [68] \\
\hline miR-Bart1-5P & $\uparrow$ & $\begin{array}{l}55 \text { cancerous and } \\
15 \text { normal } \\
\text { nasopharyngeal } \\
\text { tissues, } \\
\text { nude mice }\end{array}$ & $\begin{array}{c}\text { HONE1, HK1, } \\
\text { CNE1, 5-8F, } \\
\text { 6-10B, SUNE1, } \\
\text { HNE1 and } \\
\text { CNE2, HEK293T }\end{array}$ & $\mathrm{AMPK} \alpha 1$ & AMPK/mTOR & $\begin{array}{c}\text { miR-Bart1-5P augments glycosis, } \\
\text { proliferation, and angiogenesis } \\
\text { levels in nasopharyngeal } \\
\text { carcinoma cells. }\end{array}$ & [69] \\
\hline miR-BART6-3p & $\uparrow$ & - & $\begin{array}{l}\text { HK-1, C666-1, } \\
\text { BJAB, B95.8 }\end{array}$ & IFN- $\beta$, RIG-I & & $\begin{array}{l}\text { In EBV infected cells, } \\
\text { miR-BART6-3p impedes immune } \\
\text { response and by downregulating } \\
\text { a pattern recognition receptor. }\end{array}$ & [70] \\
\hline
\end{tabular}

\section{Impact of Drugs on the Expression of ncRNAs in Infected Patients}

EBV-miR-BART22 has been shown to promote stemness properties, metastatic abilities of cancer cells, and increase their resistance to cisplatin. This viral-encoded miRNA directly targets the MAP2K4 and up-regulates MYH9 levels through PI3K/AKT/c-Jun signaling. Notably, cinobufotalin has been found to suppress miR-BART22-associated cisplatin resistance through enhancing expression of MAP2K4 to inhibit MYH9/GSK3 $\beta / \beta$-catenin cascade and EMT process in nasopharyngeal carcinoma [71]. Another study has shown that $\mathrm{RAS}^{\mathrm{G} 12 \mathrm{~V}}$ and irinotecan up-regulate BART3-3p expression to hamper gastric cancer cells senescence and lower NK cells and macrophages infiltration. In fact, BART3-3p reduces TP53, TP21, and inflammatory cytokines such as IL-1A, IL-1B, IL-6, and IL-8 [72]. Table 7 shows the impact of drugs on the expression of ncRNAs in infected patients.

Table 7. Impact of drugs on the expression of ncRNAs in infected patients. ( $\uparrow$ upregulation; $\downarrow$ down regulation).

\begin{tabular}{|c|c|c|c|c|c|}
\hline ncRNA & $\begin{array}{c}\text { Expression } \\
\text { Pattern }\end{array}$ & Drug & Assessed Sample & Description & Reference \\
\hline miR-BART22 & $\downarrow$ & Cinobufotalin & $\begin{array}{l}\text { HONE1 and 5-8F } \\
\text { cells, } 61 \text { cancerous } \\
\text { and } 36 \text { non-cancerous } \\
\text { nasopharyngeal } \\
\text { tissues, female } \\
\text { BALB/c nude mice }\end{array}$ & $\begin{array}{l}\text { Cinobufotalin downregulates } \\
\text { miR-BART22, an ncRNA that } \\
\text { enhances metastasis and tumor } \\
\text { stemness in EBV-infected cases } \\
\text { suffering from nasopharyngeal cancer. } \\
\text { This miRNA increases cisplatin } \\
\text { resistance by increasing MYH9 levels } \\
\text { and activating } \\
\text { PI3K/AKT/c-Jun pathway. }\end{array}$ & [71] \\
\hline miR-BART3-3p & $\uparrow$ & $\mathrm{RAS}^{\mathrm{G} 12 \mathrm{~V}}$ /irinotecan & $\begin{array}{l}\text { SGC7901, KATOIII, } \\
\text { AGS, and HEK293 } \\
\text { cells lines. } 20 \text { positive } \\
\text { and } 20 \text { negative } \\
\text { gastric cancer tissues } \\
+ \text { nude mice }\end{array}$ & $\begin{array}{l}\text { These two drugs up-regulate } \\
\text { BART3-3p expression to hamper } \\
\text { gastric cancer cells' senescence and } \\
\text { lower NK cells and macrophages } \\
\text { infiltration. That is to say, BART3-3p } \\
\text { reduces TP53, TP21, and } \\
\text { inflammatory cytokines such as IL-1A, } \\
\text { IL-1B, IL-6, and IL-8. }\end{array}$ & [72] \\
\hline
\end{tabular}

\section{Diagnostic Value of Non-Coding RNAs in EBV-Infected Individuals}

Expression levels of EBV-encoded miRNAs such as miR-BART2-5p, miR-BART7$3 p$, miR-BART9-3p, and miR-BART13-3p have been shown to distinguish patients with nasopharyngeal cancer from healthy controls with diagnostic values ranging from 0.87 to 0.97 (Table 8). 
Table 8. Diagnostic Value of ncRNAs in EBV-infected individuals.

\begin{tabular}{|c|c|c|c|c|c|c|}
\hline ncRNA & Clinical Cases & AUC & Sensitivity & Specificity & Description & Reference \\
\hline miR-BART7-3p & $\begin{array}{l}483 \text { cases with } \\
\text { nasopharyngeal } \\
\text { carcinoma and } 243 \\
\text { healthy cases }\end{array}$ & 0.964 & 96.1 & 96.7 & \multirow[t]{2}{*}{$\begin{array}{l}\text { Advanced stage nasopharyngeal } \\
\text { carcinoma is markedly correlated } \\
\text { with these miRNAs } \\
\text { overexpression. Therefore, they } \\
\text { have the potential to be used as } \\
\text { biomarkers for predicting patients' } \\
\text { outcomes. }\end{array}$} & \multirow[t]{2}{*}{ [73] } \\
\hline miR-BART13-3p & & 0.973 & 97.3 & 99.6 & & \\
\hline miR-BART13-3p & \multirow[t]{3}{*}{$\begin{array}{c}\text { Serum samples from } 39 \\
\text { nasopharyngeal } \\
\text { carcinoma cases, } \\
33 \text { healthy controls, and } \\
29 \text { non-nasopharyngeal } \\
\text { cases }\end{array}$} & 0.91 & 74 & 97 & \multirow[t]{3}{*}{$\begin{array}{l}\text { Combining BART13-3p with } \\
\text { BART7-3p results in an AUC equal } \\
\text { to } 0.93 \text {, indicating the significance } \\
\text { of these miRNAs in diagnosing } \\
\text { nasopharyngeal carcinoma. }\end{array}$} & \multirow[t]{3}{*}[74]{} \\
\hline miR- BART7-3p & & 0.90 & 85 & 90 & & \\
\hline miR- BART9-3p & & 0.87 & 97 & 82 & & \\
\hline miR-BART2-5p & $\begin{array}{l}148 \text { nasopharyngeal } \\
\text { cases and } 118 \text { healthy } \\
\text { controls }\end{array}$ & 0.972 & 93.9 & 89.8 & - & {$[75]$} \\
\hline
\end{tabular}

\section{Discussion}

The interactions between ncRNAs and viral genes result in different pathophysiological consequences, thus affecting the clinical course of infection. In the current review, we have focused on the role of lncRNAs and miRNAs in HSV, CMV, and EBV infections and the induction of antiviral response. Most of the conducted studies have summarized the expression pattern of host transcripts. However, virus-derived ncRNAs have also been studied.

A possible mechanism for the oncogenic function of HSV is hijacking some cellular elements such as $\operatorname{lncRNAs}$ and miRNAs. Interference with this process possibly has therapeutic effects. Moreover, interference with viral-encoded ncRNAs might affect pathogenic processes in the course of viral infections. For instance, LAT-targeting ribozymes have been suggested as a possible strategy for treating recurrent HSV-related diseases such as herpes stromal keratitis [12].

A number of viral-encoded lncRNAs and miRNAs regulate the establishment of permanent latency, which might be a preceding phase of tumor development. Since this phase might be continued for a long time, it provides a window for therapeutic interventions in order to reverse the carcinogenic process. These viral transcripts have been shown to affect the expression of both protein-coding genes and ncRNAs encoded by the host cells. Thus, the interactions between cellular and viral ncRNAs are entirely complicated, necessitating the conduction of high throughput sequencing experiments and integrative bioinformatics analyses.

A number of cellular signaling pathways, such as NF- $\mathrm{kB}$ signaling, can affect viral latency. Additional investigations about the mechanisms by which NF- $\mathrm{KB}$ signaling can regulate the latency of viral particles might reveal novel therapeutic options for the treatment of viral-associated cancers.

Since most viral-encoded miRNAs and lncRNAs do not have similar sequences in the human genome, they can be considered appropriate diagnostic biomarkers, particularly for viral-associated malignancies. This type of application has been studies for EBV-encoded miRNAs such as miR-BART2-5p, miR-BART7-3p, miR-BART9-3p, and miR-BART13-3p, showing promising results in EBV-associated nasopharyngeal carcinoma. Further research in other types of viral-associated cancers is needed to expand the diagnostic application of these ncRNAs. 
The data presented in this review helps identify viral-related regulators and proposes novel strategies for the prevention and treatment of viral infection.

Author Contributions: S.G.-F. wrote the draft and revised it. M.T. designed and supervised the study. B.M.H., G.S. and H.H.J. collected the data and desigend the figures and tables. All authors have read and agreed to the published version of the manuscript.

Funding: This research received no external funding.

Institutional Review Board Statement: Not applicable.

Informed Consent Statement: Not applicable.

Data Availability Statement: Not applicable.

Conflicts of Interest: The authors declare no conflict of interest.

\section{References}

1. Palazzo, A.F.; Lee, E.S. Non-coding RNA: What is functional and what is junk? Front. Genetics 2015, 6, 2. [CrossRef] [PubMed]

2. Wang, L.; Cho, K.B.; Li, Y.; Tao, G.; Xie, Z.; Guo, B. Long Noncoding RNA (lncRNA)-Mediated Competing Endogenous RNA Networks Provide Novel Potential Biomarkers and Therapeutic Targets for Colorectal Cancer. Int. J. Mol. Sci. 2019, $20,5758$. [CrossRef]

3. Fang, Y.; Fullwood, M.J. Roles, functions, and mechanisms of long non-coding RNAs in cancer. Genom. Proteom. Bioinform. 2016, 14, 42-54. [CrossRef] [PubMed]

4. Bartel, D.P. MicroRNAs: Target recognition and regulatory functions. Cell 2009, 136, 215-233. [CrossRef] [PubMed]

5. Wang, P. The opening of pandora's box: An emerging role of long noncoding RNA in viral infections. Front. Immunol. 2019, 9, 3138. [CrossRef] [PubMed]

6. Josset, L.; Tchitchek, N.; Gralinski, L.E.; Ferris, M.T.; Eisfeld, A.J.; Green, R.R.; Thomas, M.J.; Tisoncik-Go, J.; Schroth, G.P.; Kawaoka, Y.; et al. Annotation of long non-coding RNAs expressed in collaborative cross founder mice in response to respiratory virus infection reveals a new class of interferon-stimulated transcripts. RNA Biol. 2014, 11, 875-890. [CrossRef]

7. Sethuraman, S.; Gay, L.A.; Jain, V.; Haecker, I.; Renne, R. microRNA dependent and independent deregulation of long non-coding RNAs by an oncogenic herpesvirus. PLoS Pathog. 2017, 13, e1006508. [CrossRef]

8. Wang, Z.; Fan, P.; Zhao, Y.; Zhang, S.; Lu, J.; Xie, W.; Jiang, Y.; Lei, F.; Xu, N.; Zhang, Y. NEAT1 modulates herpes simplex virus-1 replication by regulating viral gene transcription. Cell. Mol. Life Sci. 2017, 74, 1117-1131. [CrossRef] [PubMed]

9. Imamura, K.; Imamachi, N.; Akizuki, G.; Kumakura, M.; Kawaguchi, A.; Nagata, K.; Kato, A.; Sato, H.; Yoneda, M.; Kai, C.; et al. Long noncoding RNA NEAT1-dependent SFPQ relocation from promoter region to paraspeckle mediates IL8 expression upon immune stimuli. Mol. Cell 2014, 53, 393-406. [CrossRef]

10. Morchikh, M.; Cribier, A.; Raffel, R.; Amraoui, S.; Cau, J.; Severac, D.; Dubois, E.; Schwartz, O.; Bennasser, Y.; Benkirane, M. HEXIM1 and NEAT1 long non-coding RNA form a multi-subunit complex that regulates DNA-mediated innate immune response. Mol. Cell 2017, 67, 387-399.e5. [CrossRef]

11. Shirahama, S.; Onoguchi-Mizutani, R.; Kawata, K.; Taniue, K.; Miki, A.; Kato, A.; Kawaguchi, Y.; Tanaka, R.; Kaburaki, T.; Kawashima, H.; et al. Long noncoding RNA U90926 is crucial for herpes simplex virus type 1 proliferation in murine retinal photoreceptor cells. Sci. Rep. 2020, 10, 19406. [CrossRef]

12. Watson, Z.L.; Washington, S.D.; Phelan, D.M.; Lewin, A.S.; Tuli, S.S.; Schultz, G.S.; Neumann, D.M.; Bloom, D.C. In vivo knockdown of the herpes simplex virus 1 latency-associated transcript reduces reactivation from latency. J. Virol. 2018, 92, e00812-e00818. [CrossRef] [PubMed]

13. Li, W.; Wang, Q.; Feng, Q.; Wang, F.; Yan, Q.; Gao, S.J.; Lu, C. Oncogenic KSHV-encoded interferon regulatory factor up-regulates HMGB2 and CMPK1 expression to promote cell invasion by disrupting a complex lncRNA-OIP5-AS1/miR-218-5p network. PLoS Pathog. 2019, 15, e1007578. [CrossRef]

14. Zheng, K.; Liu, Q.; Wang, S.; Ren, Z.; Kitazato, K.; Yang, D.; Wang, Y. HSV-1-encoded microRNA miR-H1 targets Ubr1 to promote accumulation of neurodegeneration-associated protein. Virus Genes 2018, 54, 343-350. [CrossRef] [PubMed]

15. Barrozo, E.R.; Nakayama, S.; Singh, P.; Vanni, E.A.; Arvin, A.M.; Neumann, D.M.; Bloom, D.C. Deletion of herpes simplex virus 1 microRNAs miR-H1 and miR-H6 impairs reactivation. J. Virol. 2020, 94, e00639-20. [CrossRef] [PubMed]

16. Duan, Y.; Zeng, J.; Fan, S.; Liao, Y.; Feng, M.; Wang, L.; Zhang, Y.; Li, Q. Herpes Simplex Virus Type 1-Encoded miR-H2-3p Manipulates Cytosolic DNA-Stimulated Antiviral Innate Immune Response by Targeting DDX41. Viruses 2019, 11, 756. [CrossRef] [PubMed]

17. Wang, Y.; Huang, L.; Wang, Y.; Luo, W.; Li, F.; Xiao, J.; Qin, S.; Wang, Z.; Song, X.; Jin, F.; et al. Single-cell RNA-sequencing analysis identifies host long noncoding RNA MAMDC2-AS1 as a co-factor for HSV-1 nuclear transport. Int. J. Biol. Sci. 2020, 16, 1586. [CrossRef] 
18. Yao, S.; Jia, X.; Wang, F.; Sheng, L.; Song, P.; Cao, Y.; Shi, H.; Fan, W.; Ding, X.; Gao, S.J.; et al. CircRNA ARFGEF1 functions as a ceRNA to promote oncogenic KSHV-encoded viral interferon regulatory factor induction of cell invasion and angiogenesis by up-regulating glutaredoxin 3. PLoS Pathog. 2021, 17, e1009294. [CrossRef] [PubMed]

19. Wang, Z.; Li, K.; Wang, X.; Huang, W. MiR-155-5p modulates HSV-1 replication via the epigenetic regulation of SRSF2 gene expression. Epigenetics 2019, 14, 494-503. [CrossRef]

20. Venuti, A.; Musarra-Pizzo, M.; Pennisi, R.; Tankov, S.; Medici, M.A.; Mastino, A.; Rebane, A.; Sciortino, M.T. HSV-1 $\backslash$ EGFP stimulates miR-146a expression in a NF-кB-dependent manner in monocytic THP-1 cells. Sci. Rep. 2019, 9, 5157. [CrossRef]

21. Qi, Y.; Zheng, G.; Di, C.; Zhang, J.; Wang, X.; Hong, Y.; Song, Y.; Chen, R.; Yang, Y.; Yan, Y.; et al. Latency-associated nuclear antigen inhibits lytic replication of Kaposi's sarcoma-associated herpesvirus by regulating let-7a/RBPJ signaling. Virology 2019, 531, 69-78. [CrossRef] [PubMed]

22. Hussein, H.A.; Akula, S.M. miRNA-36 inhibits KSHV, EBV, HSV-2 infection of cells via stifling expression of interferon induced transmembrane protein 1 (IFITM1). Sci. Rep. 2017, 7, 17972. [CrossRef] [PubMed]

23. Xie, Y.; He, S.; Wang, J. MicroRNA-373 facilitates HSV-1 replication through suppression of type I IFN response by targeting IRF1. Biomed. Pharmacother. 2018, 97, 1409-1416. [CrossRef] [PubMed]

24. Vanni, E.A.; Foley, J.W.; Davison, A.J.; Sommer, M.; Liu, D.; Sung, P.; Moffat, J.; Zerboni, L.; Arvin, A.M. The latency-associated transcript locus of herpes simplex virus 1 is a virulence determinant in human skin. PLoS Pathog. 2020, 16, e1009166. [CrossRef] [PubMed]

25. Morrison, K.; Manzano, M.; Chung, K.; Schipma, M.J.; Bartom, E.T.; Gottwein, E. The Oncogenic Kaposi's Sarcoma-Associated Herpesvirus Encodes a Mimic of the Tumor-Suppressive miR-15/16 miRNA Family. Cell Rep. 2019, 29, 2961-2969.e6. [CrossRef] [PubMed]

26. Wang, Y.; Feldman, E.R.; Bullard, W.L.; Tibbetts, S.A. A gammaherpesvirus microRNA targets EWSR1 (Ewing sarcoma breakpoint region 1) in vivo to promote latent infection of germinal center B cells. Mbio 2019, 10, e00996-19. [CrossRef] [PubMed]

27. Li, T.; Ju, E.; Gao, S.-J. Kaposi sarcoma-associated herpesvirus miRNAs suppress CASTOR1-mediated mTORC1 inhibition to promote tumorigenesis. J. Clin. Investig. 2019, 129, 3310-3323. [CrossRef] [PubMed]

28. Zhao, Y.; Yang, J.; Liu, Y.; Fan, J.; Yang, H. HSV-2-encoded miRNA-H4 regulates cell cycle progression and Act-D-induced apoptosis in HeLa Cells by targeting CDKL2 and CDKN2A. Virol. Sin. 2019, 34, 278-286. [CrossRef] [PubMed]

29. Wang, X.; Liu, S.; Zhou, Z.; Yan, H.; Xiao, J. A herpes simplex virus type 2-encoded microRNA promotes tumor cell metastasis by targeting suppressor of cytokine signaling 2 in lung cancer. Tumor Biol. 2017, 39. [CrossRef] [PubMed]

30. Lau, B.; Kerr, K.; Gu, Q.; Nightingale, K.; Antrobus, R.; Suárez, N.M.; Stanton, R.J.; Wang, E.C.; Weekes, M.P.; Davison, A.J. Human cytomegalovirus long non-coding RNA1. 2 suppresses extracellular release of the pro-inflammatory cytokine IL-6 by blocking NF-kB activation. Front. Cell. Infect. Microbiol. 2020, 10, 361. [CrossRef] [PubMed]

31. Tai-Schmiedel, J.; Karniely, S.; Lau, B.; Ezra, A.; Eliyahu, E.; Nachshon, A.; Kerr, K.; Suárez, N.; Schwartz, M.; Davison, A.J.; et al Human cytomegalovirus long noncoding RNA4. 9 regulates viral DNA replication. PLoS Pathog. 2020, 16, e1008390. [CrossRef] [PubMed]

32. Kumar, A.; Tripathy, M.K.; Pasquereau, S.; Al Moussawi, F.; Abbas, W.; Coquard, L.; Khan, K.A.; Russo, L.; Algros, M.-P.; Valmary-Degano, S.; et al. The human cytomegalovirus strain DB activates oncogenic pathways in mammary epithelial cells. EBioMedicine 2018, 30, 167-183. [CrossRef]

33. Wang, Y.-H.; Yu, X.-H.; Qu, G.-J.; Qiao, F.-F.; Han, H. Reduced expression of the lncRNA NRON is a potential hallmark of the CMV-amplified CD8+ T cell accumulations commonly seen in older humans. Exp. Gerontol. 2019, 115, 46-54. [CrossRef] [PubMed]

34. Zhou, W.; Xi, D.; Shi, Y.; Wang, L.; Zhong, H.; Huang, Z.; Liu, Y.; Tang, Y.; Lu, N.; Wang, Y.; et al. MicroRNA-1929-3p participates in murine cytomegalovirus-induced hypertensive vascular remodeling through Ednra/NLRP3 inflammasome activation. Int. J. Mol. Med. 2021, 47, 719-731. [CrossRef]

35. Hancock, M.H.; Crawford, L.B.; Perez, W.; Struthers, H.M.; Mitchell, J.; Caposio, P. Human cytomegalovirus UL7, miR-US5-1, and miR-UL112-3p inactivation of FOXO3a protects CD34+ hematopoietic progenitor cells from apoptosis. Msphere 2021, 6, e00986-20. [CrossRef] [PubMed]

36. Liang, Q.; Wang, K.; Wang, B.; Cai, Q. HCMV-encoded miR-UL112-3p promotes glioblastoma progression via tumour suppressor candidate 3. Sci. Rep. 2017, 7, 44705. [CrossRef]

37. Zhang, S.; Liu, L.; Wang, R.; Tuo, H.; Guo, Y.; Yi, L.; Wang, D.; Wang, J. miR-138 promotes migration and tube formation of human cytomegalovirus-infected endothelial cells through the SIRT1/p-STAT3 pathway. Arch. Virol. 2017, 162, 2695-2704. [CrossRef]

38. Shi, L.; Fan, B.; Chen, D.; Guo, C.; Xiang, H.; Nie, Y.; Zhong, D.; Shi, X. Human cytomegalovirus protein UL136 activates the IL-6/STAT3 signal through MiR-138 and MiR-34c in gastric cancer cells. Int. J. Clin. Oncol. 2020, 25, 1936-1944. [CrossRef]

39. Yan, B.; Ma, H.; Jiang, S.; Shi, J.; Yang, Z.; Zhu, W.; Kong, C.; Chen, L.; Yan, H.; Ma, C. microRNA-221 restricts human cytomegalovirus replication via promoting type I IFN production by targeting SOCS1/NF-kB pathway. Cell Cycle 2019, 18, 3072-3084. [CrossRef]

40. He, X.; Teng, J.; Cui, C.; Li, D.; Wen, L. MicroRNA-182 inhibits HCMV replication through activation of type I IFN response by targeting FOXO3 in neural cells. Exp. Cell Res. 2018, 369, 197-207. [CrossRef]

41. Wang, Y.; Zhao, P.; Qian, D.; Hu, M.; Zhang, L.; Shi, H.; Wang, B. MicroRNA-613 is downregulated in HCMV-positive glioblastoma and inhibits tumour progression by targeting arginase-2. Tumor Biol. 2017, 39. [CrossRef] 
42. Hancock, M.H.; Mitchell, J.; Goodrum, F.D.; Nelson, J.A. Human cytomegalovirus miR-US5-2 downregulation of GAB1 regulates cellular proliferation and UL138 expression through modulation of epidermal growth factor receptor signaling pathways. Msphere 2020, 5, e00582-20. [CrossRef] [PubMed]

43. Hancock, M.H.; Crawford, L.B.; Pham, A.H.; Mitchell, J.; Struthers, H.M.; Yurochko, A.D.; Caposio, P.; Nelson, J.A. Human cytomegalovirus miRNAs regulate TGF- $\beta$ to mediate myelosuppression while maintaining viral latency in CD34+ hematopoietic progenitor cells. Cell Host Microbe 2020, 27, 104-114.e4. [CrossRef] [PubMed]

44. Mikell, I.; Crawford, L.B.; Hancock, M.H.; Mitchell, J.; Buehler, J.; Goodrum, F.; Nelson, J.A. HCMV miR-US22 down-regulation of EGR-1 regulates CD34+ hematopoietic progenitor cell proliferation and viral reactivation. PLoS Pathog. 2019, 15, e1007854. [CrossRef]

45. Skinner, C.M.; Ivanov, N.S.; Barr, S.A.; Chen, Y.; Skalsky, R.L. An Epstein-Barr virus microRNA blocks interleukin-1 (IL-1) signaling by targeting IL-1 receptor 1. J. Virol. 2017, 91, e00530-17. [CrossRef]

46. Shao, Y.; Qi, Y.; Huang, Y.; Liu, Z.; Ma, Y.; Guo, X.; Jiang, S.; Sun, Z.; Ruan, Q. Human cytomegalovirus miR-US4-5p promotes apoptosis via downregulation of p21-activated kinase 2 in cultured cells. Mol. Med. Rep. 2017, 16, 4171-4178. [CrossRef] [PubMed]

47. Verhoeven, R.J.; Tong, S.; Zhang, G.; Zong, J.; Chen, Y.; Jin, D.Y.; Chen, M.R.; Pan, J.; Chen, H. NF-кB signaling regulates expression of Epstein-Barr virus BART microRNAs and long noncoding RNAs in nasopharyngeal carcinoma. J. Virol. 2016, 90, 6475-6488. [CrossRef]

48. Yetming, K.D.; Lupey-Green, L.N.; Biryukov, S.; Hughes, D.J.; Marendy, E.M.; Miranda, J.L.; Sample, J.T. The BHLF1 locus of Epstein-Barr virus contributes to viral latency and B-cell immortalization. J. Virol. 2020, 94, e01215-e01220. [CrossRef] [PubMed]

49. He, B.; Li, W.; Wu, Y.; Wei, F.; Gong, Z.; Bo, H.; Wang, Y.; Li, X.; Xiang, B.; Guo, C.; et al. Epstein-Barr virus-encoded miR-BART6-3p inhibits cancer cell proliferation through the LOC553103-STMN1 axis. FASEB J. 2020, 34, 8012-8027.

50. Zheng, X.; Wang, J.; Wei, L.; Peng, Q.; Gao, Y.; Fu, Y.; Lu, Y.; Qin, Z.; Zhang, X.; Lu, J.; et al. Epstein-Barr virus microRNA miR-BART5-3p inhibits p53 expression. J. Virol. 2018, 92, e01022-18. [CrossRef]

51. Huang, T.; Ji, Y.; Hu, D.; Chen, B.; Zhang, H.; Li, C.; Chen, G.; Luo, X.; Zheng, X.W.; Lin, X. SNHG8 is identified as a key regulator of epstein-barr virus (EBV)-associated gastric cancer by an integrative analysis of lncRNA and mRNA expression. Oncotarget 2016, 7, 80990. [CrossRef]

52. Mai, S.; Xiao, R.; Shi, L.; Zhou, X.; Yang, T.; Zhang, M.; Weng, N.; Zhao, X.; Wang, R.; Liu, J.; et al. MicroRNA-18a promotes cancer progression through SMG1 suppression and mTOR pathway activation in nasopharyngeal carcinoma. Cell Death Dis. 2019, 10, 819. [CrossRef]

53. Shi, Q.; Zhang, Y.; Liu, W.; Xiao, H.; Qi, Y.; Li, J.; Luo, B. Latent membrane protein 2A inhibits expression level of Smad2 through regulating miR-155-5p in EBV-associated gastric cancer cell lines. J. Med. Virol. 2020, 92, 96-106. [CrossRef] [PubMed]

54. Wang, W.; Zhang, Y.; Liu, W.; Xiao, H.; Zhang, Q.; Wang, J.; Luo, B. LMP1-miR-146a-CXCR4 axis regulates cell proliferation, apoptosis and metastasis. Virus Res. 2019, 270, 197654. [CrossRef]

55. Anastasiadou, E.; Stroopinsky, D.; Alimperti, S.; Jiao, A.L.; Pyzer, A.R.; Cippitelli, C.; Pepe, G.; Severa, M.; Rosenblatt, J.; Etna, M.P.; et al. Epstein - Barr virus-encoded EBNA2 alters immune checkpoint PD-L1 expression by downregulating miR-34a in B-cell lymphomas. Leukemia 2019, 33, 132-147. [CrossRef] [PubMed]

56. Kim, S.-M.; Hur, D.Y.; Hong, S.-W.; Kim, J.H. EBV-encoded EBNA1 regulates cell viability by modulating miR34a-NOX2-ROS signaling in gastric cancer cells. Biochem. Biophys. Res. Commun. 2017, 494, 550-555. [CrossRef] [PubMed]

57. Gong, L.P.; Chen, J.N.; Dong, M.; Xiao, Z.D.; Feng, Z.Y.; Pan, Y.H.; Zhang, Y.; Du, Y.; Zhang, J.Y.; Bi, Y.H.; et al. Epstein-Barr virus-derived circular RNA LMP 2A induces stemness in EBV-associated gastric cancer. EMBO Rep. 2020, 21, e49689. [CrossRef] [PubMed]

58. Kase, K.; Saito, M.; Nakajima, S.; Takayanagi, D.; Saito, K.; Yamada, L.; Ashizawa, M.; Nakano, H.; Hanayama, H.; Onozawa, H.; et al. ARID1A deficiency in EBV-positive gastric cancer is partially regulated by EBV-encoded miRNAs, but not by DNA promotor hypermethylation. Carcinogenesis 2021, 42, 21-30. [CrossRef] [PubMed]

59. Wu, Y.; Wang, D.; Wei, F.; Xiong, F.; Zhang, S.; Gong, Z.; Shi, L.; Li, X.; Xiang, B.; Ma, J.; et al. EBV-miR-BART12 accelerates migration and invasion in EBV-associated cancer cells by targeting tubulin polymerization-promoting protein 1 . FASEB J. 2020 34, 16205-16223. [CrossRef] [PubMed]

60. Lung, R.W.M.; Tong, J.H.M.; Ip, L.M.; Lam, K.H.; Chan, A.W.H.; Chak, W.P.; Chung, L.; Yeung, W.W.; Hau, P.; Chau, S.; et al. EBV-encoded miRNAs can sensitize nasopharyngeal carcinoma to chemotherapeutic drugs by targeting BRCA1. J. Cell. Mol. Med. 2020, 24, 13523-13535. [CrossRef]

61. Zhang, Q.; Luo, D.; Xie, Z.; He, H.; Duan, Z. The Oncogenic Role of miR-BART19-3p in Epstein-Barr Virus-Associated Diseases. BioMed Res. Int. 2020, 2020, 5217039. [CrossRef] [PubMed]

62. Min, K.; Lee, S.K. EBV miR-BART10-3p promotes cell proliferation and migration by targeting DKK1. Int. J. Biol. Sci. 2019, 15, 657. [CrossRef] [PubMed]

63. Dong, M.; Gong, L.P.; Chen, J.N.; Zhang, X.F.; Zhang, Y.W.; Hui, D.Y.; Zhao, X.X.; Wu, X.Y.; Shao, C.K. EBV-miR-BART10-3p and EBV-miR-BART22 promote metastasis of EBV-associated gastric carcinoma by activating the canonical Wnt signaling pathway. Cell. Oncol. 2020, 43, 901-913. [CrossRef] [PubMed]

64. Song, Y.; Li, Q.; Liao, S.; Zhong, K.; Jin, Y.; Zeng, T. Epstein-Barr virus-encoded miR-BART11 promotes tumor-associated macrophage-induced epithelial-mesenchymal transition via targeting FOXP1 in gastric cancer. Virology 2020, 548, 6-16. [CrossRef] 
65. Liu, J.; Zhang, Y.; Liu, W.; Zhang, Q.; Xiao, H.; Song, H.; Luo, B. MiR-BART1-5p targets core 2 $\beta-1,6$-acetylglucosaminyltransferase GCNT3 to inhibit cell proliferation and migration in EBV-associated gastric cancer. Virology 2020, 541, 63-74. [CrossRef]

66. Huang, J.; Qin, Y.; Yang, C.; Wan, C.; Dai, X.; Sun, Y.; Meng, J.; Lu, Y.; Li, Y.; Zhang, Z.; et al. Downregulation of ABI2 expression by EBV-miR-BART13-3p induces epithelial-mesenchymal transition of nasopharyngeal carcinoma cells through upregulation of c-JUN/SLUG signaling. Aging 2020, 12, 340. [CrossRef]

67. Cristino, A.S.; Nourse, J.; West, R.A.; Sabdia, M.B.; Law, S.C.; Gunawardana, J.; Vari, F.; Mujaj, S.; Thillaiyampalam, G.; Snell, C.; et al. EBV microRNA-BHRF1-2-5p targets the 3' UTR of immune checkpoint ligands PD-L1 and PD-L2. Blood 2019, 134, 2261-2270. [CrossRef]

68. Zhou, X.; Zheng, J.; Tang, Y.; Lin, Y.; Wang, L.; Li, Y.; Liu, C.; Wu, D.; Cai, L. EBV encoded miRNA BART8-3p promotes radioresistance in nasopharyngeal carcinoma by regulating ATM/ATR signaling pathway. Biosci. Rep. 2019, 39, BSR20190415. [CrossRef]

69. Lin, C.; Zong, J.; Lin, W.; Wang, M.; Xu, Y.; Zhou, R.; Lin, S.; Guo, Q.; Chen, H.; Ye, Y.; et al. EBV-miR-BART8-3p induces epithelial-mesenchymal transition and promotes metastasis of nasopharyngeal carcinoma cells through activating NF- $\mathrm{KB}$ and Erk1/2 pathways. J. Exp. Clin. Cancer Res. 2018, 37, 283. [CrossRef]

70. Xu, Y.J.; Zhou, R.; Zong, J.F.; Lin, W.S.; Tong, S.; Guo, Q.J.; Lin, C.; Lin, S.J.; Chen, Y.X.; Chen, M.R.; et al. Epstein-Barr virus-coded miR-BART13 promotes nasopharyngeal carcinoma cell growth and metastasis via targeting of the NKIRAS2/NF- $\mathrm{B}$ pathway. Cancer Lett. 2019, 447, 33-40. [CrossRef]

71. Lyu, X.; Wang, J.; Guo, X.; Wu, G.; Jiao, Y.; Faleti, O.D.; Liu, P.; Liu, T.; Long, Y.; Chong, T.; et al. EBV-miR-BART1-5P activates $\mathrm{AMPK} / \mathrm{mTOR} / \mathrm{HIF} 1$ pathway via a PTEN independent manner to promote glycolysis and angiogenesis in nasopharyngeal carcinoma. PLoS Pathog. 2018, 14, e1007484. [CrossRef] [PubMed]

72. Lu, Y.; Qin, Z.; Wang, J.; Zheng, X.; Lu, J.; Zhang, X.; Wei, L.; Peng, Q.; Zheng, Y.; Ou, C.; et al. Epstein-Barr virus miR-BART6-3p inhibits the RIG-I pathway. J. Innate Immun. 2017, 9, 574-586. [CrossRef]

73. Liu, Y.; Jiang, Q.; Liu, X.; Lin, X.; Tang, Z.; Liu, C.; Zhou, J.; Zhao, M.; Li, X.; Cheng, Z.; et al. Cinobufotalin powerfully reversed EBV-miR-BART22-induced cisplatin resistance via stimulating MAP2K4 to antagonize non-muscle myosin heavy chain IIA/glycogen synthase $3 \beta / \beta$-catenin signaling pathway. EBioMedicine 2019, 48, 386-404. [CrossRef] [PubMed]

74. Wang, J.; Zheng, X.; Qin, Z.; Wei, L.; Lu, Y.; Peng, Q.; Gao, Y.; Zhang, X.; Zhang, X.; Li, Z.; et al. Epstein-Barr virus miR-BART3-3p promotes tumorigenesis by regulating the senescence pathway in gastric cancer. J. Biol. Chem. 2019, 294, 4854-4866. [CrossRef] [PubMed]

75. Lu, T.; Guo, Q.; Lin, K.; Chen, H.; Chen, Y.; Xu, Y.; Lin, C.; Su, Y.; Chen, Y.; Chen, M.; et al. Circulating Epstein-Barr virus microRNAs BART7-3p and BART13-3p as novel biomarkers in nasopharyngeal carcinoma. Cancer Sci. 2020, 111, 1711. [CrossRef] 